\title{
The Jihadi Current and the Lay Thinking: A "Re-Anchorage" Process Hypothesis
}

\author{
Dorra Ben Alaya \\ Tunis El Manar University, \\ 94 Rommana St, Tunis, 1068, Republic of Tunisia \\ $\checkmark$ d.benalaya@gmail.com
}

\begin{abstract}
The Jihadi-salafist doctrine which is at the Islamist terrorism origin that affects several countries since the emergence of Al Qaeda in the late 80's, gave birth to the "Islamic State of Iraq and Sham/Levant" (ISIS/ISIL) established as a "Caliphate" in 2014. Despite the ISIS official military defeat in 2019, the Jihadi-Salafist current - whose history goes back a long way, is currently behind a number of attacks whether collective or individual, claimed by known organizations or committed in isolation. In our perspective, we try to apprehend the attraction power of the Jihadi narrative issue taking the Theory of Social Representations as a paradigmatic framework. This implies that we don't consider the Jihadi current membership as the manifestation of a deviation from normality or optimal rationality, but as the expression of a certain common sense "resonance". More precisely, and taking the case of the Tunisian context, the success of the Jihadi narrative is explained by its effectiveness as an interpretive grid and as a guide for action, making it possible to "re-anchor" a reality lacking in meaning. This hypothesis of a "re-anchoring" implies that anchoring as described by Moscovici as one of the two processes at the origin of the social representations formation (with the objectification process), could be not only as a familiarization of the strange by inserting it in an already known pre-existing frame, but by substituting to the frame itself, a new one, in order to be able to insert familiar objects which would have lost their sense precisely because of the old frame itself. This hypothesis could offer a theoretical and heuristic perspective allowing the anchoring process to be conceived as a circular and non-definitive process.
\end{abstract}

Key words: social representations theory, Djihadi-Salafism, anchoring process, re-anchoring, Tunisia

\section{Introduction}

What is named from 2014, as the "Islamic State of Iraq and Sham/Levant" (ISIS/ISIL) or DAESH (an acronym formed from the organization's Arabic designation $^{2}$ ) refers to the main face of what is called the organized "global terrorism" af-

(C) Ben Alaya D., 2021

(c) () This work is licensed under a Creative Commons Attribution 4.0 International License https://creativecommons.org/licenses/by/4.0/

\footnotetext{
${ }^{1}$ Terrorist organization banned in Russia.
}

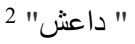


ter Al Kaida had experienced a certain setback. The ISIS proto-State (proclaimed as a "Caliphate") has been characterized by a staged violence and by spectacular attacks as mode of action but also as an argument for its propaganda.

Nowadays, even though ISIS has been militarily defeated, in 2019, the political-islamist current that is at its base, stills manifest through attacks in different regions in the world. According to statistics ${ }^{3}$, from the beginning of 2021 and if only the actions of organized groups are considered, it was responsible for at least 11591 attacks worldwide and concerns the five most deadly organizations. Many of the attacks are still carried out on behalf organized groups as Taliban, Boko Haram, ISIS (as an idological current) or Al-Shabaab, but some others are perpetrated "in the name of Islam" by isolated individuals who do not explicitly belong to any organized Islamist network. They generally use rudimentary means, often a bladed weapon and with cries of "Allah akbar" (Allah is the greatest). Those attacks aren't claimed by known organizations. According to Kepel (2021), they are linked to "an atmosphere" of Jihadism ("au djihadisme d'atmosphère").

The ISIS as a topical "Caliphate" and as a doctrinal current, appears as the material and concrete place of what terrifies, of what creates disorder and of what transgresses all known rules of what makes the modern Nation-States and societies. Concerning the European countries, nor should we forget the role played by a historical background dating back to the Crusades, and even further, in the ISIS problem anchoring in a pre-existing imaginary, opposing "East" and "West", Islam and Christianity, "civilized" and "barbaric" world, imaginary which caracterises the theses of authors as Huttington $(1993,1996)$ using the notion of clash between the vague concept of opposed "civilizations". In Muslimmajority countries as Tunisia, Jihadism is officially presented as a deviation from a "true" Islam, and the Jihadi doctrine as a sham. In short, whether in Europe or in Muslim-majority countries (as Tunisia, Egypt, etc.), the problem of Islamist terrorism is apprehended in the dominant discourses through a same reading grid: that of a break with normality.

\section{Scientific Approaches to the Phenomenon of Jihadi}

This has led many scholars from different disciplines to focus on either what characterizes Jihadi individuals or to examine what it is about Islam itself that generates islamist violence. Thousands of studies have attempted to identify the leading factors to the ISIS membership. There are at micro, meso and macro levels of analysis, ranging from geostrategic to psychological, sociological or political science. At each of these levels, numerous factors interaction and combination contribute to the explanation of what is referred to as "violent extremism" (Ranstorp, Hyllengren, 2013). This shows the phenomenon complexity and the unresolved difficulty of reaching a solution that could prevent violent actions.

With regard to sociological studies, many of them aim explicitly or implicitly to respond to the urgent need to prevent or counter current membership and recruitment by seeking to identify the living conditions or the individual trajectories

${ }^{3}$ Statista. (2021). Number of fatalities due to terrorist attacks worldwide in 2019 , by responsible terrorist group. Retrieved May 29, 2021, from https:/www.statista.com/statistics/517683/tenmost-violent-terrorist-groups-2015-by-number-of-attacks/ 
role leading to violent action. However, identifying unambiguously decisive factors at the general level in the organization membership, seems to be a difficult task. Neither the degree of poverty nor the education or the origin country religiosity level, are determining factors. According to a World Bank report $(2016)^{4}$, only the country's overall male unemployment rate seems to correlate with the recruits number, while at the same time, and according to the same report, the majority say they worked in a trade before joining the organization... According to the report, another important finding is that recruits "are far from being uneducated or illiterate". $69 \%$ of them report at least a secondary education, only $15 \%$ left school before high school and less than $2 \%$ are illiterate. Concerning recruits from the Middle East, North Africa and South and East Asia, "they are significantly more educated than individuals from their cohort in their region of origin. Most has attended secondary school and a large fraction has gone on to study at university". But what is even more surprising is their initial relationship to the Islamic religion. With regard to the Muslim religion knowledge, their own assessments of their knowledge of it, show low levels of knowledge: only 4\% consider that they have a confirmed religion knowledge. The majority (53\%) consider their knowledge "basic" and 20\% consider it at the "intermediate" level. In addition, the country religiosity degree is negatively correlated with the ISIS recruits number. In conclusion, the report states that it is the combination of the country's high unemployment rate and a high level of education which has a high probability of leading to "radical" ideas.

From a psychosocial perspective which considers that the lay thinking is a study object in itself, and more particularly in the Social Representations Theory framework (Moscovici, 1961), we consider the Jihadi current attraction exerted among certain individuals, taking into account the interactions between what the jihadi narrative proposes and what their representations of the context in which they evolve, echoes it.

But first of all, we must specify that the so-called "radical" ideas belong to an Islam minority movement, namely Jihadi-Salafism (this shoud'nt be confused with Salafism", which can be only "activist" or "quietist"...) as it stands today (Rougier, 2008), i.e. in a total social and political rupture logic with the NationStates model. This is probably the reason why the "Islamist political ideology" as categorized by many social science authors, is generally described in reference to the "radicalism" or "radicalization" concepts (as it was already the case for the anarchist movement in the late 19th - early 20th century or of the far left actions in the 1970s, in Europe) which Khosrokhavar describes as follows (2014. P. 8) "the process by which an individual or group adopts a violent form of action, directly linked to an extremist ideology..." Jihadi-Salafism is characterized by, among other things, being selective in the sacred references (i.e. the Koran and

4 The World Bank. (2016). Economic and social inclusion to prevent violent extremism. Retrieved November 26, 2018, from https://documents.worldbank.org/en/publication/documentsreports/documentdetail/409591474983005625/economic-and-social-inclusion-to-prevent-violentextremism

5 The root of the word ("Salaf", "سلف"), means in Arabic "pious ancestors" or "predecessors"' (Rougier, 2008). 
hadiths $s^{6}$ ) and by the violence use as a mean of establishing the only legitimate political and social governance model in the eyes of the doctrine. It should be noted however, that this is a trend whose history is not recent. It dates back to the 8-9th century AD, i.e. Handbalism (Laoust, 1959; Charnay, 2008), one of the four leading jurisprudence ("مذهب") schools that form Sunni Muslim law, founded by Ibn$\mathrm{Hanbal}^{7}$ whose primary concern was to restore strict respect for the Koran and the prophetic tradition (Nader, 1956), in the face of the emergence of new currents of thinking (particularly that of Mu'tazilites ${ }^{8}$ inspired by the Greek philosophy), and to disqualify the interpretation of the sacred texts activities designated as "innovation" ("بدعة"), which is a pejorative concept in this context. In the 13th century, Ibn-Taymiyya ${ }^{9}$, heir to Hambalism, took up the torch and criticized the rationalist philosophers of the time - particularly Ibn-Rochd (Averroes) - whom he considered heretics and as the "Aristotle religion" followers whose reference framework is a "polytheistic thinking"; and; secondly, some rites forms that he describes as "deviant", such as Sufism ${ }^{10}$ (a mystic Islam current existing since the 9th century) ${ }^{11}$ which, at that time, began to be organized (Guenon, 1973; Houtsma, Arnold, Wensinck, 1913-1936), or the saints cult (Massignon, 1975/2010). Then, AbdelWahhab (18th century) gave a new lease of life to the Jihadi-Salafism as in its current form. He participated in the founding of a Salafist governance characterized by a great rigorism, that of Saudi Arabia (Lage, 2006). From the doctrinal point of view in relation to his predecessors, Abdel-Wahhab ${ }^{12}$ introduced the excommunication principle ("تكفير "I") and the idea according to which many of those who believe they are Muslim are not true ones due to the "idols" they associate with God ("شرك"). Therefore they are accused by him of polytheism, apostasy or miscreance. They are literally "those who associate" ("مشركون"), punishable by the death penalty. In the 20th century, Qutb ${ }^{13}$ - a member of the early Egyptian Muslim Brotherhood - by promulgating violent struggle as legitimate, even compulsory political action against Arab nationalist and socialist regimes and the "West", in modern Jihadism (Carré, Seurat, 1983) was one of those who gave new impetus to the modern Jihadism. At the organizational and active level, Azzam at the 80's, then since 2001, Bin Laden, founder of Al Qaeda, Al-Zawahiri, and, distinguishing themselves from the latter, Zarkawi and Al-Baghdadi ("Caliph" of the ISIS) among others, are the main representatives of the Jihadi current (Bé-

${ }^{6}$ The Prophet Mohammed Words and facts compiled in reference works (six in number) such as that of $A l-B u k h \bar{a} r \bar{\imath}$ (9th century) known as "Sahīh al-Bukhār $\vec{\imath}$ " (صحيح||بخاري") or as that of Muslim (9th century) known as "Sahīh Muslim" ("صحيح مسلم")...

${ }^{7}$ Ibn-Hanbal, A. (1895). "Musnad". Bulaq.

${ }^{8}$ Tenants of Mu'tazilism, a Sunni Islam current probably founded by Ibn-Ata in the 8th century.

${ }^{9}$ Ibn Taymiyya, A. (2007). "Al'Aqida Al Wasitiyya". Dar Al Muslim.

${ }^{10}$ A mystical doctrine of Islam organized in brotherhoods ("طرق").

${ }^{11}$ Al-Hallaj (9th century) and Ibn-Arabi (13th century) were representatives of the movement.

${ }^{12}$ Abdel-Wahhab. Kitâb ut-tawhîd. Retrieved October 28, 2018, from http://bayt.al.hikma.free.fr/la_croyance/livre_unicite.html

${ }^{13}$ Qutb, S. (2002). In the Shade of the Qur'an (vol. 30). Retrieved October 20, 2018, from https://www.kalamullah.com/shade-of-the-quran.html 
nichou, Khosrokhavar, Migaux 2015; Rogozinski, 2017). They have led to the Jihad globalization while placing it in an apocalyptic perspective. At the same time, a massive dissemination of Jihadi literature both that from the origins and that more recent (in particular that of Al-Maqdissi, Abou Qatada, Abou Moussab...) at the international level, developed through the new communication technologies and the virtual social networks constituting extremely efficient vehicles for the Jihadi ideas (Khosrokhavar, 2014).

Since the first work on "Jihadi terrorism" that could be traced back to Etienne (1987), the thinking of "political Islamism" in which Jihadi-Salafism is classified, has been decoded, often by applying an analysis in terms of ideology, by making use of a predefined conceptual framework that in social psychology refers to general, non-specific mental processes. According to Maher (2017), Jihadi-Salafism is a political-religious ideology built around five principles: jihad ${ }^{14}$ (which literally means "effort" in Arabic and which refers in Salafist-Jihadist doctrine to the obligation to armed struggle), the oneness of $\mathrm{God}^{15}$, the excommunica$\operatorname{tion}^{16}$, the covenant and disavowal ${ }^{17}$ (broadly referring to the idea that a Muslim would only be a Muslim if he disavows non-Muslims), and absolute divine sovereignty (which refers to what Salafist literature more precisely refers to in Arabic, literally, as the "unification of the sovereignty"18).

In social psychology, the definition of the ideology notion is not without some difficulties. Those given, are often equivocal, non-operational and questionable (Roussiau, Bonardi, 2001). The notion refers to the idea of a particular sociocognitive system or functioning of "self-explanation" and "self-legitimization" (Deconchy, 1989. P. 242). In Deconchy's terms (2000. P. 118), it is a "specific cognitive posture". According to this author $(1989,1999)$, it is a coherent system of reality explanations and representations, based on a conviction among its supporters of the veracity of its content considered as "true", without any "rational" verification. It "is as a natural perceiving and explaining framework for events, that is, as realism... Hence the concept of epistemo-ideology" (Camus, 2004). It is characterized by making the product of contingencies, as an historical and logical necessity (Deconchy, 1999. P. 119). Within this conceptual framework, the ideological explanation system is considered as opposed to an optimal thinking system whose prototypical form would be the scientific verification. This conceptual framework - like any theoretical framework - is not exempt from implications: first, the contents of ideologies are studied only as particularisms; and second, the ideology notion refers to an unusual functioning. It is associated with the orthodoxy notion which according to Deconchy (1971. P. 35), characterizes an individual who "accepts, and even asks, that his thinking, language and behaviour being regulated by the ideological group to which he belongs and in particular by the group power apparatuses". Generally, the adherence to Jihadi-Salafist doctrine is implicitly interpreted as a sort of "madness", an abnormality, often

$$
\begin{aligned}
& \text { "النجهاد" } 14 \\
& \text { "الَّوَحيد" } 15 \\
& \text { "التكفير" } 16 \\
& \text { "أو لاء وذبر اء" } 17 \\
& \text { "توحيد||حاكمية" } 18
\end{aligned}
$$


signified by being "out of the ordinary". This idea is clearly expressed through certain definitions of Islamist "radicalism", such as Bernier's (2016), according to which it is an "unusual way" expression, and may eventually lead to the use of "non-ordinary means". The phenomenon analyzes are generally based on two postulates: that of a clear rupture between an "erroneous" information processing versus a valid one, an individual rationality versus a collective irrationality, an optimal cognitive functioning versus a biased one; and a more specific and implicit one (even among social sciences scholars) of a clear limit between a supposed Muslim "ordinary", "moderate", "reasonably religious" common sense, and a "radicalized" way of thinking. The first postulate, an epistemic one, refers to a "preliminary and fixed conception of what thinking should be" as expressed by Moscovici (2013. P. 227), i.e. the idea of a norm, that of a "normality" of thinking versus a biased one. These are the presuppositions of a dominant cognitivism in social psychology, undermined by the social thinking paradigm as initiated by Moscovici (1961, 1976). By introducing common sense knowledge as a legitimate scientific object in the social sciences, he reintroduces the reflective and symbolic dimension of human social behavior (Greenwood, 2004, cited by Kalampalikis, 2013. P. 9). The paradigm has also a far-reaching epistemological implication: rationality is no longer the prerogative of the individual or the scientific thinking; and it is no longer defined according to the veracity criteria according to an objective reality. By taking up the legacy of Durkheim and Levy-Bruhl who questioned the dichotomy made between the modern societies rationality and the "primitive" societies irrationality, Moscovici (2013. P. 46) affirms that "all that is rational is social and all that is social is rational". He refers to "the rationality of popular knowledge". He stipulates that social thinking would have its own rationality whose logic derives from the social situations and which is generated by the social relations constraints $(1961 ; 1976)$. It is based on the collective construct of meanings need, in order to act. In this perspective, Jihadi way of thinking can be interpreted as a certain "knowledge mode" expression that is contextually determined. It is an "evaluative knowledge" Beauvois (1984) that makes sense in the eyes of its members. But before continuing, we should specify that what is expressed here is a purely epistemological posture which must not be interpreted as a legitimizing attempt of the Jihadi actions nor the doctrine. What is proposed here is only to consider this thinking form from its own logic taken in a phenomenological way and in relation to the particular contexts of its diffusion, in the hope of better understanding the dynamics of the actions it claims. Given the difficulty of defining a typical profile ${ }^{19}$ of the violent Jihadi ready to carry out an attack, it is, in our opinion, towards the Jihadi thinking internal elements and their echoe with the context, which we must look to find a way of explanation. It is on the basis of these proposals that we have sought to understand the tremendous attraction and fascination power the Jihadi thinking exerts on its supporters. As an illustration of its powerful attraction, a United-Nations experts report ${ }^{20}$ notes that until August

19 A report title (137 nuances of terrorism, Hecker, 2018) itself, express the impasse by focusing exclusively on what makes individuals and their unique trajectories joining the Jihadi movement.

${ }^{20}$ Report submitted to the United Nations Security Council on 23 August 2018. Retrieved September 26, 2018, from https://documents-dds-ny.un.org/doc/UNDOC/GEN/N18/261/77/pdf 
2018, between 20,000 and 30,000 Jihadis were still fighting in the ISIS ranks despite the military setbacks it was undergoing. In addition, there are 3000 to 4000 fighters in Libya, as well as those in Southeast Asia and West Africa. In the Tunisian context which is of particular interest to us, Tunisia has counted between 2011 (year of the fall of the dictatorship of Ben Ali) and 2018, around 3000 jihadist fighters in Iraq, Libya and Syria, which is proportionally important considering the 11 million inhabitants, according to the National Commission for Combating Terrorism (coted by International Crisis Group, 2013 ${ }^{21}, 2021^{22}$ ). Currently, about 300 Tunisians still fighting. In addition, Tunisian fellows committed four attacks in France and Germany in 2016 and 2021.

\section{The Theory of Social Representations as a paradigmatic framework for the Jihadi narrative analysis}

We consider that the internal Jihadi "rationality" and consistency would have a reality structuring power among those who adhere to it. Thus, in the same way as an idea formulated by Crettiez (2011), the assumption underlying our reflection is that of a "resonance" (Snow, Benford, 1988) of the Jihadi narrative as it currently circulates, with a loss of meaning of the key notions that underlie the collective life in a "modern" Nation-State among the lay thinking in Tunisia as formulated by Ben Alaya (2013). This meaning loss would be the result of the dictatorship several decades of Ben Ali's regime during which the notions of human rights were used to promote an idyllic image of the country, while the authorities practiced a violent repression. Since the fall of the regime in 2011. Succeeded an important social, economic and political crisis and a large part of the Tunisian State authorities have lost much of their credibility and the confidence of the population due to a disappointment of expectations regarding the restoration of the rule of law (Ben Alaya, 2015). This is accompanied by a very strong sense of injustice, humiliation and lack of recognition among young people (Melliti, Moussa, 2018; Ben Alaya, 2015, Ben Alaya, Ben Ismail, Hanine, 2020). More importantly, Ben Alaya's work shows that young Tunisians from different backgrounds, manifest a pragmatic paradox experience in the sense of the Palo Alto systemic theory of (c. f. Bateson, 1995; Winkin, 1981) due to recurring doublebind situations in which they face concrete interactions and experiences that totally invalidate the explicit official narratives about democracy, institutions, justice, equality and human rights. The only issue that remains in a such context is to deny the reality to which the dominant thinking categories refers. This category thinking system is considered by young people as principles that are "imported from Europe". In other words, there is a meaning loss of the rule of law notions that are disabled by concrete experience. It is, in our opinion, in the context of this loss that the Jihadi narrative imposes its own thinking framework or reading grid.

${ }^{21}$ International Crisis Group. (2013). Tunisia: Violence and the Salafi Challenge. Retrieved June 7, 2021, from https://www.crisisgroup.org/middle-east-north-africa/north-africa/tunisia/tunisiaviolence-and-salafi-challenge

${ }^{22}$ International Crisis Group. (2021). Jihadism in Tunisia: A Receding Threat? Retrieved June 7, 2021, from https://www.crisisgroup.org/middle-east-north-africa/north-africa/tunisia/jihadisme-entunisie-eviter-la-recrudescence-des-violences 
To formalize this, we use the description of one of the Social Representations formation processes as described by Moscovici (1961; 1976): the Anchoring. This recourse seems adequate as a social representation is formed facing an "ordinary experience rupture (which) triggers meanings and explanations search of what strikes us as strange and disturbing" (Moscovici, 2013. P. 109). However, it should be noted that in our approach, the anchoring process should concern a "familiar" object that has become "unfamiliar"; Or more precisely, it should concern what we thought being familiar and which surprises us for not being in adequacy with the social interactions reality. It is as if the referents, once anchored in a "modernist" reference framework, had lost their meaning because the framework itself had become a source of ambiguity and strangeness. In contrast to the anchoring process as usually described, there would be the adoption of a new framework for "re-anchoring" the objects that we thought were known and that they have fallen into the strangeness. The anchoring as defined by Moscivici (1961) is the process by which pre-existing frameworks of thought are implemented to apprehend novelty. Except that in our concern, the objects are already known and it is the frame that is new. It would be the substitution of one framework by another to reinterpret in a new way, the already existing objects. The aim of anchoring in this case would not be familiarizing strangeness, but resolving a paradox, re-familiarizing the "known" that is no longer familiar (which would be in concordance with Kruglansky and Webster's theory $(1996 ; 1994)$ of intolerance towards ambiguity among extremists).

The hypothesis of a re-anchorage process implies that anchoring could be circular, and could lead to a first period of characterization of the object. The stigmatization of once-familiar "non-Muslims" in Jihadism could be one of the origins of this demotion into "being to be killed". To explain the power of this imperative to annihilate this "stranger" who is the "miscreant", "associator to God" or "heretic", we can take up the notion of stigmatic anchoring formulated by Moscovici (2002) who notes: "...his presence [the stranger] is felt... as a disorder that one cannot ignore. The deficiency we feel is the deficiency of a common world. More specifically, a loss of familiarity or coherence in the way of being in the group. This is why the awareness of this loss is an existential problem that affects the whole person" (p. 23).

In view of the above, Jihadi thinking would find its place in contexts where none of the categorization systems in place among collectives has the power to integrate key objects that govern the "living together". Alongside the fundamental texts of Jihadi-Salafist narrative as it currently circulates, responds in the long term to the need to give a new meaning to the experienced problems, while offering keys to exit, presented as effective and definitive. For the "injustices" and "inequalities" imposed by "a State that favors only the rich" (Ben Alaya, Ben Ismail, Hanine, 2020), it substitutes a divine, supra-human right, the just and equitable nature of which constitutes its very essence concretized by the law of retaliation ${ }^{23}$. To the "contempt" shown by "the rich classes" for the "poor classes" (Ben Alaya, Ben Smail, Hanine, 2020), it imposes a hierarchy based on loyalty to God and where each person can, by his own faith and conduct (in other words by his own

"قصاص" 23 
means), reach the highest ranks. To a difficulty in projecting oneself into the future, he offers an infinite perspective of eternity through a very elaborate eschatological vision and apocalyptic narrative. To the feeling of helplessness in the face of difficult events and living conditions, he invites the individual to play an active role not only in his own life, but also in an epic progression of the world and in the inevitable destiny of the divine will. In a few words, Jihadi thinking restores in the individual in search of meaning, through his participation in a community of elected representatives (that of the "true" Muslims) ${ }^{24}$, a self-glorious image and a power, which one believes distorted by the failing law of men.

\section{Conclusion}

It is by taking into consideration the meanings conveyed by the Jihadi narrative, in correspondence with those existing (or vacant) among the common sense and in a particular context, that the influence of the Jihadi thinking can be understood. The implications are multiple. First, an exploration of common sense thinking as a whole, i.e. extended to a non-Jihadi population, seems useful, if not essential, to understand the possible relevance of the doctrine to individuals. Secondly, it means that explicit adherence to Jihadi thinking would not be in total rupture with the "ordinary" collective social representations, but in a resonance relationship. Another point should be raised. It is to "ordinary" aspirations that Jihadi thinking claims to respond. "justice", "equality", "equity", "respect"... are values to which explicit reference is made by the Jihadi propaganda. Putting the analyzes made in a radical opposition framework with the "ordinary" referents, could be a dead end. Nevertheless, it should be noted that in Salafist doctrine in general, the source of these values and the means to implement them, are considered as external to the social and to the human and are therefore considered as absolutely infallible excluding any dialectic.

\section{References}

Bateson, G. (1995). Vers une écologie de l'esprit (Vols. I et II). Paris: Points.

Beauvois, J.L. (1989). La psychologie quotidienne. Paris: Presses Universitaires de France.

Ben Alaya, D. (2013). The Tunisian revolution. An object under construction. Papers on Social Representations, 22, 2.1-2.19.

Ben Alaya, D. (2015). Jeunes et problèmes de société-Etude de base 2. Tunis: The National Youth Observatory \& Canada: The International Development Research Centre (Canada).

Ben Alaya, D., Ben Ismail, R., \& Hanine, M. (2020). Pensée sociale et extrémisme violent: résonnances et résistances, Report, Tunis: The Tunisian Forum for Social and Economic Development. Retrieved March 18, 2021, from https://www.ftdes.net/rapports/extremisme.fr.pdf

Bénichou, D., Khosrokhavar, F., \& Migaux, P. (2015). Le jihadisme: Le comprendre pour mieux le combattre. Paris: Plon.

Bernier, G. (2016). Radicalisme. Dichotomie entre croyance et tolérance. Paris: L'Harmattan.

Bruno Etienne, B. (1987). L'islamisme radical. The Muslim West and the Mediterranean Revew, $44,150-151$.

Camus, O. (2004). L'épistémo-idéologie libérale. Normes sociales et processus cognitif. SACO \& MSHS Proceedings (pp. 23-26). Poitiers: Poitiers University.

24 The "Umma" ("أمّة"). 
Carré, O., \& Seurat, M. (1983). Les Frères musulmans (1928-1982). Paris: L'Harmattan.

Charnay, J.P. (2008). Esprit du droit musulman. Paris: Dalloz.

Crettiez, X. (2011a). High risk activism. Essai sur le processus de radicalisation (première partie). Pôle Sud, (1), 45-60. https://doi.org/10.3917/psud.034.0045

Crettiez, X. (2011b). High risk activism. Essai sur le processus de radicalisation. Pôle Sud, (2), 97-110. https://doi.org/10.3917/psud.034.0045

Deconchy, J.-P. (1971). L'orthodoxie religieuse. Paris: Ouvrières Editions

Deconchy, J.P. (1989). Psychologie sociale. Croyances et idéologies. Paris: Méridien Kincksiek.

Deconchy, J.P. (1999). Psychologie sociale des processus idéologiques. In J.L. Beauvois, N. Dubois, \& W. Doise (Eds.), La construction sociale de la personne (vol. 4, pp. 113-128). Grenoble: Grenoble University Press.

Deconchy, J.-P. (2000). Les processus idéologiques. In N. Roussiau (Ed.), Psychologie sociale (pp. 113-120). Paris: Press Editions.

El Karoui, H., \& Hodayé, B. (2021). Les militants du djihad. Portrait d'une generation. Paris: Fayard.

Greenwood, J.-D. (2004). The Disappearance of the social in the American social psychology. Cambridge: Cambridge University Press.

Guenon, R. (1973). Aperçus sur l'ésotérisme islamique et le taoïsme (vol. 182). Paris: Gallimard.

Hecker, M. (2018). Jihadistes in France face à la justice justice. IFRI studies, Strategic Focus, 79.

Houtsma, M.Th., Arnold, T.W., \& Wensinck, A.J. (1913-1936). "Tașawwuf ". In Brill's First Encyclopaedia of Islam (vol. VIII, pp. 681-682). Leiden: Brill.

Huttington, S. (1993). The clash of civilizations? Foreign Affairs, 72(3), 22-49.

Huttington, S. (1996). The Clash of Civilizations and the Remaking of World Order. NY: Simon \& Schuster.

International Crisis Group (2013). Tunisie: Violences et défis salafistes, $\mathrm{n}^{\circ} 137$, Middle East \& North Africa. Retrived June 7, 2021, from https://d2071andvip0wj.cloudfront.net/tunisiaviolence-and-the-salafi-challenge-french.pdf

Kalampalikis, N. (2013). Foreword. In S. Moscovici (Ed.), Le scandale de la pensée sociale (pp. 7-18). Paris: Ecole des Hautes Etudes en Sciences Sociales.

Kepel, G. (2021). Le prophète et la pandémie. Du Moyen-Orient au djihadisme d'atmosphère. Paris: Gallimard.

Khosrokhavar, F. (2014). Radicalisation. Paris: Maison des Sciences de l'Homme Editions.

Kruglanski, A.W., \& Webster, D.M. (1996). Motivated closing of the mind: "Seizing" and "freezing". Psychological Review, 103, 263-283.

Lage, O. de. (2006). Géopolitique de l'Arabie Saoudite. Complexe.

Laoust, H. (1959). Le Hanbalisme sous le califat de Bagdad. Revue Des Études Islamiques, $27,67-128$.

Maher, S. (2016). Salafi-Jihadism, the history of an idea. London: Hurst \& Company.

Massignon, L. (1975; 2010). La Passion de Hallâj. Paris: Gallimard.

Melliti, I., \& Moussa, H. (2018). Quand les jeunes parlent d'injustice. Paris: L'Harmattan.

Moscovici, S. (1961; 1976). La psychanalyse, son image et son public. Paris: France University Press.

Moscovici, S. (2002). Pensée stigmatique et pensée symbolique. Deux formes élémentaires de la pensée sociale. In C. Garnier (Ed.), Les formes de la pensée sociale (pp. 21-44). Paris: Presses Universitaires de France.

Moscovici, S. (2013). Le scandale de la pensée sociale. Paris: Ecole des Hautes Etudes en Sciences Sociales Editions.

Nader, A.N. (1956). Le Système Philosophique des Mu'tazila (Premiers Penseurs de l'Islam). Beyrouth: Les Lettres Orientales.

Ranstorp, M., \& Hyllengren, P. (2013). Förebyggande av våldsbejakande extremism I tredjeland. Stockholm: Swedish Defence College.

Rogozinski, J. (2017). Djihadisme: le retour du sacrifice. Bilbao: Desclée de Brouwer. 
Rougier, B. (2008). Qu'est-ce que le salafisme. Paris: France University Press.

Rougier, B. (2021). Les territoires concquis de l'islamisme. Paris: France University Press.

Roussiau, N., \& Bonardi, C. (2001). Les représentations sociales: état des lieux et perspectives. Auderghem: Mardaga Editions.

Snow, D.A., \& Benford, R.D. (1988). Ideology, frame resonance, and participant mobilization. International Social Movement Research, 1(1), 197-217.

Webster, D.M., \& Kruglanski, A.W. (1994). Individual differences in need for cognitive closure. Journal of Personality and Social Psychology, 67, 1049-1062.

Winkin, Y. (1981). La nouvelle communication. Paris: Points.

\title{
Article history:
}

Received: 3 April 2021

Revised: 10 May 2020

Accepted: 20 May 2021

\section{For citation:}

Ben Alaya, D. (2021). The Jihadi current and the lay thinking: A "re-anchorage" process hypothesis. RUDN Journal of Psychology and Pedagogics, 18(2), 363-373. http://dx.doi.org/10.22363/2313-1683-2021-18-2-363-374

\section{Bio note:}

Dorra Ben Alaya, Ph.D in Social Psychology, is currently a social psychology lecturer at the Higher Institute of Human Sciences of Tunis, Tunis El Manar University (Tunis, Tunisia). Her researches are part of the Social Thinking current. As such, she is a member of the Serge Moscovici Worldwide Network (REMOSCO, Maison des Sciences de l'Homme, Paris). She has been for many years conducting research in the Tunisian context, with the aim of understanding the collective socio-cognitive logics underlying the "living together" foundations, discrimination or violent extremism. E-mail: d.benalaya@gmail.com

DOI 10.22363/2313-1683-2021-18-2-363-374

Теоретическая статья

\section{Джихадизм и обыденное мышление: гипотеза процесса "повторного якорения"}

\author{
Д. Бен Алайя \\ Тунисский университет Эль-Манар, \\ Тунисская Республика, 1068, Тунис, ул. Rоттапа, д. 94 \\ $\checkmark$ d.benalaya@gmail.com
}

\begin{abstract}
Аннотация. Доктрина джихадистов-салафитов, лежащая в основе исламистского терроризма, поразившего несколько стран с момента появления Аль-Каиды в конце 1980-х годов, дала начало «Исламскому государству Ирака и Леванта» (ИГИЛ/ИГ $\left.{ }^{25}\right)$, созданному как «халифат» в 2014 году. Несмотря на официальное военное поражение ИГИЛ в 2019 году, джихадистско-салафитское течение, история которого уходит корнями в далекое прошлое, в настоящее время стоит за рядом атак, ответственность за которые взяли ор-
\end{abstract}

25 Террористическая организация, запрещенная в России. 
ганизации или одиночные исполнители, и развивается в направлении того, что Ж. Кепел называет «атмосферой джихадизма». В исследовании предпринята попытка объяснить, почему джихадистский нарратив находит своих сторонников, взяв за парадигмальную основу теорию социальных представлений С. Московиси. Другими словами, принадлежность к джихадистскому течению рассматривается не как проявление отклонения от нормальности или оптимальной рациональности, но как выражение определенного «резонанса» здравого смысла (в понимании Д. Сноу и Р. Бенфорда). Если обратиться к контексту Туниса, то успех джихадистского нарратива объясняется возможностью его использования в качестве интерпретационной сетки и руководства к действию, что позволяет «повторно заякорить» реальность, лишенную смысла. Предлагаемая гипотеза о «повторном якорении» (re-anchoring) подразумевает, что якорение (anchoring), описанное Московиси как один из двух процессов, лежащих в основе формирования социальных представлений (наряду с процессом объективации) о чем-то новом, странном, незнакомом, может происходить не только путем введения нового объекта в уже известную, ранее существовавшую «рамку», но и как замена самой «рамки» на новую. В свою очередь, это позволяет поместить знакомые объекты, утратившие свой смысл именно из-за старой «рамки», в новую. Высказанная гипотеза может предложить теоретическую и эвристическую перспективу, позволяющую представить процесс «якорения» как циклический и неопределенный процесс.

Ключевые слова: теория социальных представлений, джихадизм-салафизм, процесс якорения, повторное якорение, Тунис

\section{История статьи:}

Поступила в редакцию: 3 апреля 2021 г.

Принята к печати: 20 мая 2021 г.

\section{Для цитирования:}

Ben Alaya D. The jihadi current and the lay thinking: a "re-anchorage" process hypothesis // Вестник Российского университета дружбы народов. Серия: Психология и педагогика. 2021. Т. 18. № 2. С. 363-374. http://dx.doi.org/10.22363/2313-1683-202118-2-363-374

\section{Сведения об авторе:}

Бен Алайя Дорра, Ph.D, преподаватель социальной психологии в Высшем институте гуманитарных наук Туниса, Тунисский университет Эль-Манар (Тунис, Тунис). Занимается исследованиями процессов социального мышления. Является членом Serge Moscovici Worldwide Network (REMOSCO, Maison des Sciences de l'Homme, Paris). В течение многих лет проводит исследования с целью понимания коллективной социально-когнитивной логики, лежащей в основе как концепции Living Together, так и дискриминации или насильственного экстремизма, в тунисском контексте. E-mail: d.benalaya@gmail.com 